\title{
Low temperature reduction of hexavalent chromium by a microbial enrichment consortium and a novel strain of Arthrobacter aurescens Rene' N Horton*1, William A Apel2 ${ }^{2}$, Vicki S Thompson ${ }^{2}$ and Peter P Sheridan ${ }^{1}$
}

Address: ${ }^{1}$ Department of Biological Sciences, Idaho State University, Campus Box 8007, Pocatello, ID USA $83209-8007$ and ${ }^{2}$ Idaho National Laboratory, P.O. Box 1625, Idaho Falls, ID USA 83415

Email: Rene' N Horton* - hortrene@isu.edu; William A Apel - william.apel@inl.gov; Vicki S Thompson - vicki.thompson@inl.gov; Peter P Sheridan - sherpete@isu.edu

* Corresponding author

Published: 25 January 2006

BMC Microbiology 2006, 6:5 doi:10.1186/147|-2/80-6-5

This article is available from: http://www.biomedcentral.com/l47I-2/80/6/5

(C) 2006 Horton et al; licensee BioMed Central Ltd.

This is an Open Access article distributed under the terms of the Creative Commons Attribution License (http://creativecommons.org/licenses/by/2.0), which permits unrestricted use, distribution, and reproduction in any medium, provided the original work is properly cited.

\begin{abstract}
Background: Chromium is a transition metal most commonly found in the environment in its trivalent $[\mathrm{Cr}(\mathrm{III})]$ and hexavalent $[\mathrm{Cr}(\mathrm{VI})]$ forms. The EPA maximum total chromium contaminant level for drinking water is $0.1 \mathrm{mg} / \mathrm{l}(0.1 \mathrm{pPm})$. Many water sources, especially underground sources, are at low temperatures (less than or equal to 15 Centigrade) year round. It is important to evaluate the possibility of microbial remediation of $\mathrm{Cr}(\mathrm{VI})$ contamination using microorganisms adapted to these low temperatures (psychrophiles).
\end{abstract}

Results: Core samples obtained from a $\mathrm{Cr}(\mathrm{VI})$ contaminated aquifer at the Hanford facility in Washington were enriched in Vogel Bonner medium at 10 Centigrade with 0, 25, 50, 100, 200, 400 and $1000 \mathrm{mg} / \mathrm{l} \mathrm{Cr}(\mathrm{VI})$. The extent of $\mathrm{Cr}(\mathrm{VI})$ reduction was evaluated using the diphenyl carbazide assay. Resistance to $\mathrm{Cr}(\mathrm{VI})$ up to and including $1000 \mathrm{mg} / \mathrm{Cr}(\mathrm{VI})$ was observed in the consortium experiments. Reduction was slow or not observed at and above $100 \mathrm{mg} / \mathrm{l} \mathrm{Cr}(\mathrm{Vl})$ using the enrichment consortium. Average time to complete reduction of $\mathrm{Cr}(\mathrm{VI})$ in the 30 and $60 \mathrm{mg} / \mathrm{l} \mathrm{Cr}(\mathrm{Vl})$ cultures of the consortium was 8 and 17 days, respectively at 10 Centigrade. Lyophilized consortium cells did not demonstrate adsorption of $\mathrm{Cr}(\mathrm{VI})$ over a 24 hour period. Successful isolation of a $\mathrm{Cr}(\mathrm{VI})$ reducing organism (designated $\mathrm{P} 4$ ) from the consortium was confirmed by $16 \mathrm{~S}$ rDNA amplification and sequencing. Average time to complete reduction of $\mathrm{Cr}(\mathrm{VI})$ at 10 Centigrade in the 25 and $50 \mathrm{mg} / \mathrm{Cr}(\mathrm{VI})$ cultures of the isolate $\mathrm{P} 4$ was 3 and 5 days, respectively. The I6S rDNA sequence from isolate P4 identified this organism as a strain of Arthrobacter aurescens, a species that has not previously been shown to be capable of low temperature $\mathrm{Cr}(\mathrm{VI})$ reduction.

Conclusion: A. aurescens, indigenous to the subsurface, has the potential to be a predominant metal reducer in enhanced, in situ subsurface bioremediation efforts involving $\mathrm{Cr}(\mathrm{VI})$ and possibly other heavy metals and radionuclides. 


\section{Background}

Chromium is a transition metal most commonly found in the environment in its trivalent $\left(\mathrm{Cr}^{3+}\right)$ and hexavalent $\left(\mathrm{Cr}^{6+}\right)$ forms [1]. Naturally occurring $\mathrm{Cr}$ is almost exclusively in the trivalent state, as the energy required for its oxidation is high. Hence, the hexavalent form is usually considered to be a man-made product [2]. The toxicities of the two forms of chromium are vastly different. Trivalent chromium is generally a nontoxic, nonmobile micronutrient [3]. Hexavalent chromium is water soluble, toxic, and carcinogenic, and is considered a pollutant by the United States Environmental Protection Agency (EPA) [4]. Chromium is the second most common inorganic contaminant of groundwater at hazardous waste sites [5]. The solubility and negative charge of its more common forms, chromate and dichromate $\left(\mathrm{CrO}_{4}{ }^{2-}\right.$, and $\left.\mathrm{HCrO}_{4}^{-}\right)$, lead to limited adsorption in aquifer minerals, and results in high mobility of $\mathrm{Cr}^{6+}$ in aquifers [6]. The historical and present day contamination of groundwater and soils by $\mathrm{Cr}^{6+}$ is a result of its industrial uses, including metal plating (for corrosion resistance), pigment production, and lumber and wood products (for preservation) [7].

Many water sources are at low temperatures year round $\left(\leq 15^{\circ} \mathrm{C}\right)$ and it is important to evaluate the possibility of remediating $\mathrm{Cr}^{6+}$ contamination using microorganisms adapted to these low temperatures (psychrophiles). Limitations of bioremediation processes at low temperatures have been described in the past as having slow biomass build-up rates, slow degradation and low loads [8]. Furthermore, many bioremediation processes depend on anaerobic $\mathrm{Cr}^{6+}$ reduction and it is commonly believed that anaerobic bioreactors are particularly hard to operate at ambient groundwater temperatures [8]. Recent efforts have tested the possibilities for aerobic and anaerobic low temperature bioremediation of contaminants other than $\mathrm{Cr}^{6+}$ including biostimulation and bioaugmentation [9$11]$.

To date, there have been few reports of psychrophilic $\mathrm{Cr}^{6+}$ reducing organisms [12]. Mesophilic genera capable of $\mathrm{Cr}^{6+}$ reduction include: Acinetobacter [13], Aerococcus [14], Aeromonas [14], Aspergillus [15], Bacillus [16], Corynebacterium [17], Deinococcus [18], Desulfomicrobium [19], Desulfovibrio [20], Enterobacter [21-23], Escherichia [24,25], Microbacterium [26], Micrococcus [14], Ochrobactrum [13], Pseudomonas [27-29], Rhodobacter [30], Shewanella [31], Staphylococcus [32], Streptomyces [33], Vibrio [34], and Zoogloea [35]. Since mesophilic $\mathrm{Cr}^{6+}$ reduction can proceed both aerobically and anaerobically [36], it is reasonable to assume that psychrophilic reductions will also proceed both aerobically and anaerobically. Most studies referenced were performed at temperatures at or above $20^{\circ} \mathrm{C}$. The single low temperature $\left(10^{\circ} \mathrm{C}\right)$ study involving a soil community and varying electron acceptors yielded

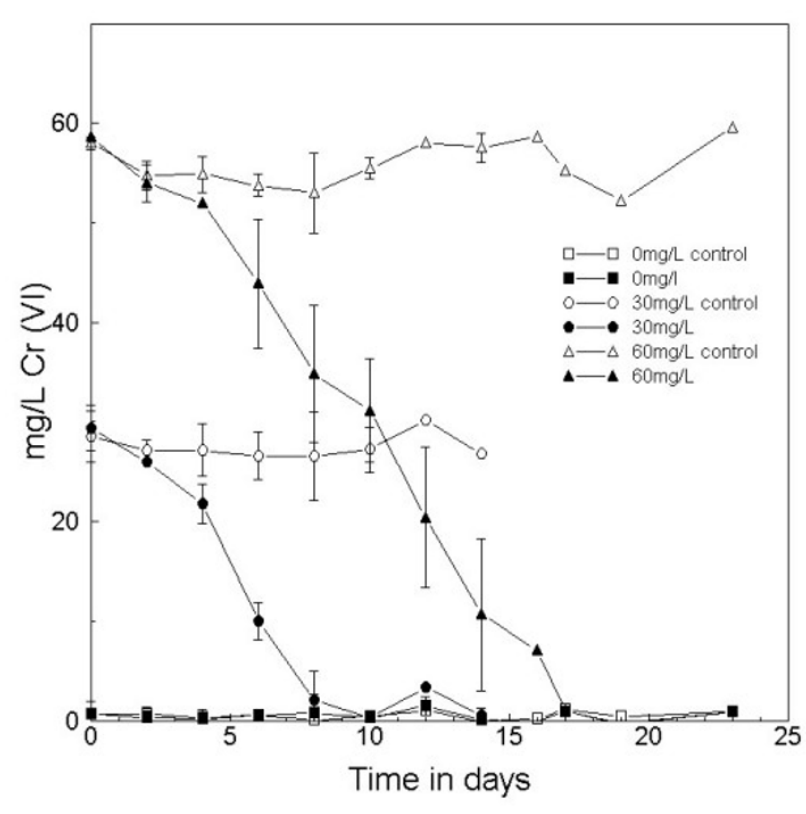

Figure I

$\mathrm{Cr}^{6+}$ reduction by enrichment consortia under aerobic conditions at $10^{\circ} \mathrm{C}$. Upon complete reduction of $\mathrm{Cr}^{6+}$ no further data was collected and is represented on the graph by the truncation of the lines for both the reduction and its similar control.

significant reduction of $\mathrm{Cr}^{6+}[12]$. To the best of our knowledge, no low temperature groundwater studies (saturated zone of aquifer) on the reduction of $\mathrm{Cr}^{6+}$ have been performed. The use of indigenous psychrophilic microorganisms may provide insight into many of the problems associated with low temperature remediation.

This study used samples obtained from a $\mathrm{Cr}^{6+}(\sim 1.3 \mathrm{mg} / \mathrm{l})$ contaminated site within the Hanford aquifer http:// www.hanford.gov/ as inocula from which indigenous psychrophilic microorganisms were cultured and tested for their ability to reduce $\mathrm{Cr}^{6+}$ to levels below the required EPA minimum. Identification of psychrophilic Cr-reducing community members will allow future studies of remediation possibilities using indigenous populations at other sites as well as help guide the search for other closely related psychrophilic microorganisms for use in remediating $\mathrm{Cr}^{6+}$ present in low temperature environments.

\section{Results}

\section{Enrichments}

Enrichments with $\mathrm{Cr}^{6+}$ concentrations from 0 to $400 \mathrm{mg} / \mathrm{l}$ showed growth in the form of turbidity (cell density approximately $10^{8} / \mathrm{mL}$ ) at $10^{\circ} \mathrm{C}$. Subsequent transfers of cultures to like concentrations of $\mathrm{Cr}^{6+}$-containing media also produced turbidity. Clearing of the VB broth (addi- 
tion of chromate turned the broth yellow) to colorless or pale white and formation of a white precipitate occurred in the 30 and $60 \mathrm{mg} / \mathrm{l} \mathrm{Cr}^{6+}$ concentration enrichments and in a preliminary reduction study, but not in the uninoculated controls. Enrichments attempted in media containing $\mathrm{Cr}^{6+}$ concentrations of $>1000 \mathrm{mg} / \mathrm{L}$ grew poorly.

\section{Consortium reduction experiments}

All enrichment cultures showed evidence of $\mathrm{Cr}^{6+}$ removal as the decolorization of media (from yellow to clear) and measurement of the decreasing $\mathrm{Cr}^{6+}$ concentration by the diphenyl carbazide assay. Standards and controls in each of the experiments were used to compare the amount of $\mathrm{Cr}^{6+}$ left in the media at approximately 48 hour intervals. No reduction was observed in cell-free controls. The overall averages and standard deviations of the three samples taken from each of the triplicate tubes in the three serial reduction experiments are represented by data provided in Figure 1. The enrichments containing $30 \mathrm{mg} / \mathrm{l} \mathrm{Cr}{ }^{6+}$ were completely reduced in approximately 8 days at $10^{\circ} \mathrm{C}$ and the $60 \mathrm{mg} / \mathrm{l} \mathrm{Cr}^{6+}$ proceeded to zero in less than 17 days at $10^{\circ} \mathrm{C}$.

\section{Isolations}

In order to select for organisms that were both resistant to $\mathrm{Cr}^{6+}$ and able to reduce $\mathrm{Cr}^{6+}$, the original enrichments were performed at high levels of $\mathrm{Cr}^{6+}$. Streaking for isolation on VB plates (without $\mathrm{Cr}^{6+}$ ) from a $1000 \mathrm{mg} / \mathrm{l} \mathrm{Cr}^{6+}$ liquid enrichment yielded an isolate (designated $\mathrm{P} 4$ ).

\section{Isolate reduction experiments}

Isolate P4 cultures showed evidence of $\mathrm{Cr}^{6+}$ removal in $\mathrm{VB}$ media as the decolorization of media (from yellow to clear) and measurement of the decreasing $\mathrm{Cr}^{6+}$ concentration by the diphenyl carbazide assay similar to the consortium reduction experiments. Standards and controls in each of the experiments were used to compare the amount of $\mathrm{Cr}^{6+}$ left in the media at approximately 12 hour intervals. P4 grew poorly in VB media without the addition of $\mathrm{Cr}^{6+}$. No reduction was observed in the cell-free controls. The overall averages and standard deviations of the three samples, taken from each of the triplicate tubes in the three serial reduction experiments, are represented by data provided in Figure 2. The enrichments containing $25 \mathrm{mg} /$ $1 \mathrm{Cr}^{6+}$ were completely reduced in less than 72 hours at $10^{\circ} \mathrm{C}$ and the $50 \mathrm{mg} / \mathrm{l} \mathrm{Cr}^{6+}$ proceeded to zero in less than 120 hours at $10^{\circ} \mathrm{C}$.

\section{Consortium adsorption experiments}

$\mathrm{Cr}^{6+}$ removal was not evidenced in adsorption experiments. Consortium cells suspended in deionized water and $\mathrm{Cr}^{6+}$ retained the yellow color of $\mathrm{Cr}^{6+}$-contaminated media. Concentrations of $\mathrm{Cr}^{6+}$ were statistically unchanged by the end of the 24 hour period as measured using the diphenyl carbazide assay. Temperature did not affect the adsorption experiments.

\section{I6S rDNA Identification and phylogenetic analysis of isolate P4}

PCR amplification and subsequent sequencing yielded an approximately $1.5 \mathrm{kbp}$ DNA fragment consistent with the expected length of the amplification product. A fragment of 1373 unambiguous bases was used in the search and analysis of related microorganisms. Ribosomal Database Project and Genbank database searches both resulted in the high sequence homology (1369/1373 bases) to Arthrobacter aurescens. Subsequent phylogenetic analysis also revealed the isolate to be a strain of A. aurescens (Figure 3).

\section{Discussion}

This study demonstrates that indigenous microbial populations present in $\mathrm{Cr}^{6+}$-contaminated aquifers are able to aerobically catalyze the removal of toxic and soluble $\mathrm{Cr}^{6+}$ from the media, most likely reducing it to the relatively nontoxic and insoluble $\mathrm{Cr}^{3+}$. The absence of $\mathrm{Cr}^{6+}$ in the media, in addition to the lack of adsorption demonstrated by the three separate adsorption experiments, suggests the $\mathrm{Cr}^{6+}$ was reduced to the less toxic $\mathrm{Cr}^{3+}$ form. Further experimentation with cell lysates of $\mathrm{P} 4$ at $18^{\circ} \mathrm{C}$ showed $\mathrm{Cr}^{6+}$ reduction activity in the soluble protein fraction, not the membrane bound protein fraction, also suggesting enzymatic reduction (data not shown). The low temperature $\left(10^{\circ} \mathrm{C}\right)$ used in the experiments and the timeline for the reductions also suggests that $\mathrm{Cr}^{6+}$ can be remediated in a reasonable amount of time at the low environmental temperatures present in many aquifers. In comparison, a mesophilic isolate from another study, Arthrobacter crystallopoites strain ES $32[37,38]$ reported a lower rate of chromate reduction at $30^{\circ} \mathrm{C}$ when compared to isolate $\mathrm{P} 4$ at $10^{\circ} \mathrm{C}$. Interestingly, ES 32 had a higher temperature optimum for $\mathrm{Cr}^{6+}$ reduction than for optimal cell growth [38]. The lack of previous low temperature studies is clearly demonstrated by a search of the literature in which only a single paper by Tseng and Bielefeldt [12] on the low temperature biotransformation of hexavalent chromium in soil is found.

Both the consortium and $\mathrm{P} 4$ isolate cultures were shown to grow and reduce $\mathrm{Cr}^{6+}$ at $10^{\circ} \mathrm{C}$. Significant biomass of the $\mathrm{P} 4$ isolate could be generated within 2 days of growth in $\mathrm{R}_{2}$ broth at $10^{\circ} \mathrm{C}$ (cell densities of $10^{8} / \mathrm{ml}$ ). Studies using mesophilic microorganisms from genera such as Bacillus, Pseudomonas and Escherichia [16,28,39] all required incubation at temperatures well above those used in this study and those found in the aquifer environment we are targeting for bioremediation. 


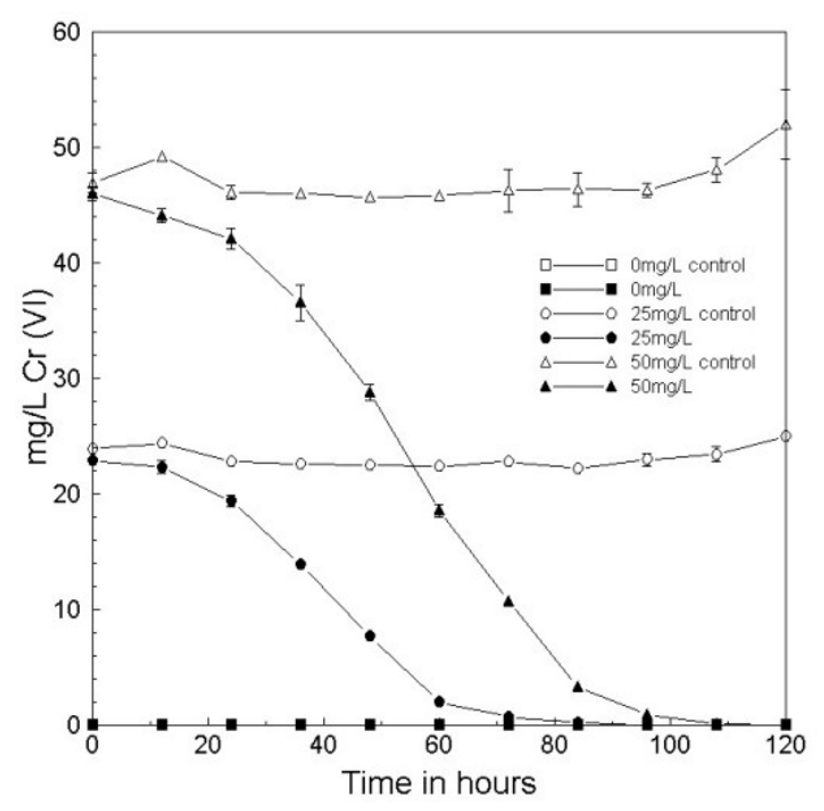

Figure 2

$\mathrm{Cr}^{6+}$ reduction by isolate $\mathrm{P} 4$ under aerobic conditions at $10^{\circ} \mathrm{C}$.

A number of studies suggest both growth-dependent and growth-independent chromium reduction $[20,29,40]$. In either case, chromium reduction does seem to be biomass dependent in our study as well as in others $[21,41]$. The lag at the beginning of the consortium reduction experiments as well as observations of increased turbidity throughout the experiments suggests that adequate cell biomass must be produced before reduction begins in earnest. Bopp and Ehrlich [28] showed that higher concentrations $(1000 \mathrm{mg} / \mathrm{l})$ of $\mathrm{Cr}^{6+}$ produced a much longer lag phase and a significantly lower final yield of biomass than lower concentrations. The reduced biomass would also contribute to the lack of complete reduction found at higher concentrations in many studies $[22,25]$ as well as in the higher concentrations tested in our lab (data not shown). Previous studies using cellular biomass grown on uncontaminated substrates to test $\mathrm{Cr}^{6+}$ reduction greatly decreased the amount of time required to completely reduce $\mathrm{Cr}^{6+}[21,39]$, similar to our findings with the isolate $\mathrm{P} 4$ reduction experiments (Figure 2). Increased turbidity after only 24 hours in $\mathrm{R}_{2}$ broth at $10^{\circ} \mathrm{C}$ (grown aerobically) and the achievement of stationary phase (as determined by absorbance readings, 1:10 dilution in R2 broth, $\mathrm{OD}=0.16$ ) after 3 days suggests that $\mathrm{P} 4$ is relatively fast growing. P4 grew at 10,18 , and $25^{\circ} \mathrm{C}$ but not at $37^{\circ} \mathrm{C}$ suggesting the isolate is a true psychrophile. Growth appeared fastest at $18^{\circ} \mathrm{C}$. The ability to increase biomass in a short time given the proper nutrients suggests that $\mathrm{P} 4$ could be useful in bioremediation using nutrient addition.

The enrichment culture and isolate P4 consistently reduced $\mathrm{Cr}^{6+}$ in $\mathrm{VB}$ medium up to concentrations of 60 $\mathrm{mg} / \mathrm{l} \mathrm{Cr}{ }^{6+}$. Higher concentrations seemed to inhibit reduction, although growth was slower but still observed as turbidity in the enrichments (data not shown). Dilution of the $\mathrm{Cr}^{6+}$ at $1000 \mathrm{mg} / \mathrm{L}$ may have affected the limited range of the diphenyl carbazide assay, causing the appearance of the lack of reduction at higher concentrations. Both the consortium and isolate $\mathrm{P} 4$ showed significant tolerance of $\mathrm{Cr}^{6+}$ up to concentrations of $1000 \mathrm{mg} / \mathrm{l}$ (data not shown) as well as measurable reduction over short periods of time at concentrations up to $60 \mathrm{mg} / \mathrm{l} \mathrm{Cr}^{6+}$. This tolerance is greater than or comparable to most mesophilic microorganisms tested, such as Pseudomonas fluorescens at 53.5 $\mathrm{mg} / \mathrm{l}$ [27] and Bacillus sp. at $500 \mathrm{mg} / \mathrm{l}$ [42]. Furthermore, the isolate $\mathrm{P} 4$ and consortium reductions presented here occurred at temperatures close to $30^{\circ} \mathrm{C}$ lower than in the studies using mesophilic organisms, suggesting that the enzyme(s) responsible for the reduction are truly coldactive.

Complete reduction was observed in all experiments (both consortium and isolate P4) with concentrations of $\mathrm{Cr}^{6+}$ up to $60 \mathrm{mg} / \mathrm{l}$ (Figures $1 \& 2$ ) suggesting that complete reduction in the environment is also possible. The lack of reduction in the sterile controls along with the lack of $\mathrm{Cr}^{6+}$ adsorption to cell biomass in the three adsorption experiments suggests that the members of the enrichment community (which included isolate $\mathrm{P} 4$ ) were responsible for the reduction of $\mathrm{Cr}^{6+}$. Since most aquifers contaminated with $\mathrm{Cr}^{6+}$ have levels below $60 \mathrm{mg} / \mathrm{l}$, these experiments would also suggest remediation of the lower levels of $\mathrm{Cr}^{6+}$ contamination present in aquifers is possible. Bioremediation literature suggests low levels of contamination are very difficult to completely remediate. Lack of induction of enzyme systems at low contaminant concentrations and problems with availability of contaminants bound to organics and sequestered in other matrices all contribute to persistence of contaminants in the environment. It has also been suggested that indigenous microorganisms may be more successful in reducing low contaminant concentrations [8]. The complete reduction of $\mathrm{Cr}^{6+}$ at $10^{\circ} \mathrm{C}$ in this study using an indigenous member of the Hanford microbial community and past studies with indigenous mesophilic microorganisms suggest that there are environmental candidates for reduction of the low levels of contamination usually found in aquifers $[23,43]$.

Studies have shown Arthrobacter species adsorbing Fe, Cd, and $\mathrm{Cu}$, but not $\mathrm{Cr}[44,45]$. Chromium has, however, been shown to adsorb to both Shewanella and Bacillus species [46]. Adsorption studies performed on the Hanford 


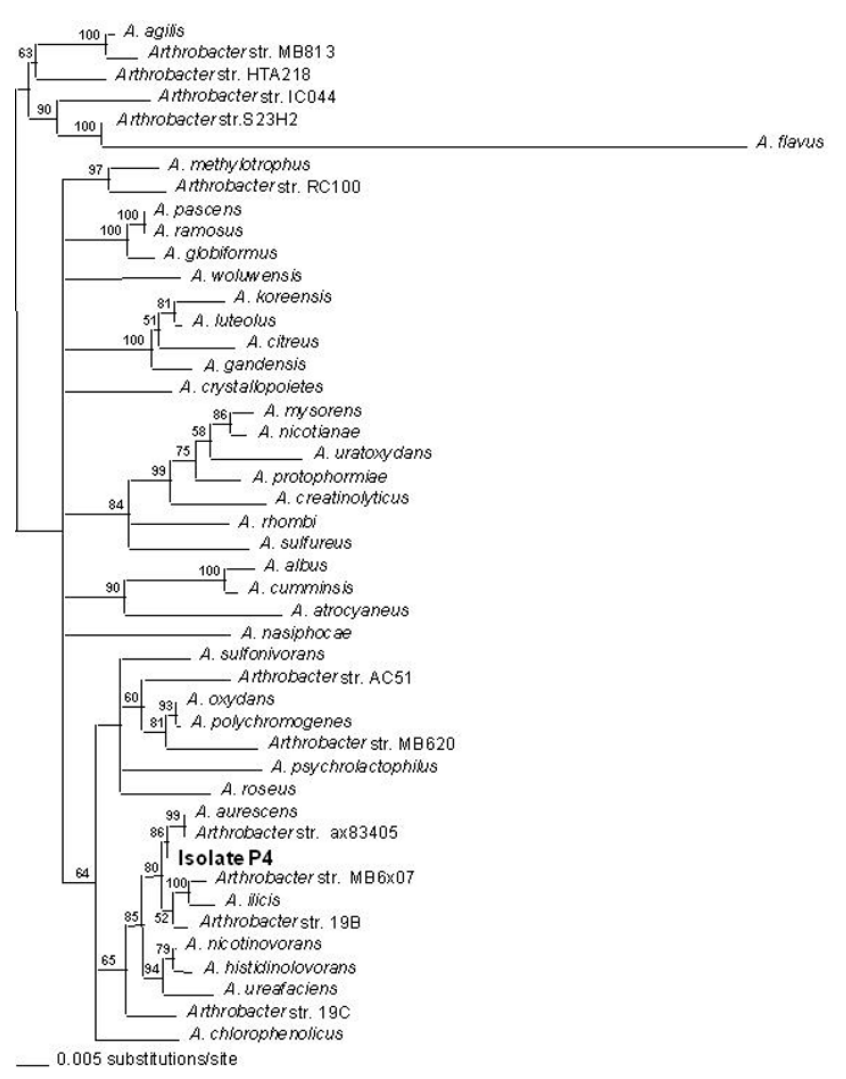

Figure 3

Distance Analysis phylogenetic tree of Arthobacter species including the isolate P4.

consortium in our laboratory (which included the isolate P4) did not show significant removal of $\mathrm{Cr}^{6+}$ due to adsorption. Three separate adsorption studies used killed (autoclaved) cells, metabolically inhibited live cells, or lyophilized cells. None of these studies showed significant adsorption of $\mathrm{Cr}^{6+}$ within 24 hours of $\mathrm{Cr}^{6+}$ addition. These, along with studies showing activity in the soluble fraction of lysate, suggest enzymatic reduction.

A few Arthrobacter species, like A. oxydans and A. crystallopoites strain ES32 have been noted previously to reduce $\mathrm{Cr}^{6+}[37,47]$. Identification of $A$. oxydans to the species level in the previous study was performed via Fatty Acid Methyl Ester (FAME) analysis, while ES 32 was characterized by $16 \mathrm{~S}$ rDNA sequencing. Carmargo et al. [37] showed ES 32 to have its optimum $\mathrm{Cr}^{6+}$ reduction in a temperature range of $30-35^{\circ} \mathrm{C}$, but did not test its $\mathrm{Cr}^{6+}$ reduction rates below $25^{\circ} \mathrm{C}$. P4, by comparison, grew well and reduced $\mathrm{Cr}^{6+}$ at $10^{\circ} \mathrm{C}$ at a faster rate than ES 32 at $30-$ $35^{\circ} \mathrm{C}$. Further comparison of the two organisms (P4 and ES 32) reveals a much lower starting concentration of $\mathrm{Cr}^{6+}$ for the reduction studies using ES $32(1.04 \mathrm{mg} / \mathrm{L} \mathrm{[38]} \mathrm{and}$ $2.0 \mathrm{mg} / \mathrm{L}$ [37]). Reduction of $\mathrm{Cr}^{6+}$ using $\mathrm{P} 4$ at $10^{\circ} \mathrm{C}$ pro- ceeded at a rate 5.5 times faster than ES 32 at $30^{\circ} \mathrm{C}(0.72$ $\mathrm{mg} / \mathrm{L} / \mathrm{h}$ and $0.13 \mathrm{mg} / \mathrm{L} / \mathrm{h}$ respectively, calculated using the linear portion of the reduction curve for both organisms). As for $\mathrm{Cr}^{6+}$ resistance, isolate P4 tolerated up to $1000 \mathrm{mg} /$ $\mathrm{L} \mathrm{Cr}^{6+}$ while isolate ES 32 was from a group that had low tolerance above $500 \mathrm{mg} / \mathrm{L} \mathrm{Cr}^{6+}$ [37]. Within these comparisons, isolate $\mathrm{P} 4$ is more resistant and reduces higher concentrations of $\mathrm{Cr}^{6+}$ at a significantly faster rate.

In the current study, the identification of isolate $\mathrm{P} 4$ as a strain of $A$. aurescens was performed via $16 \mathrm{~S}$ rDNA sequencing with comparison to sequences found in the Ribosomal Database Project and the GenBank database at NCBI. To the best of our knowledge, the species A. aurescens has not been previously associated with $\mathrm{Cr}^{6+}$ reduction.

\section{Conclusion}

Considering the ubiquity of organisms in the genus Arthrobacter, we suggest further exploration of the in situ metal reduction potential of this under-studied genus. Resistance and tolerance of Arthrobacter spp. have been demonstrated to a wide variety of heavy metals including mercury, chromium, lead, nickel and copper $[48,49]$. That, together with Arthrobacter's ability to reduce $\mathrm{Cr}^{6+}$ and other toxic metals, indicates that Arthrobacter spp. indigenous to the subsurface have potential to be useful metal reducers in enhanced, in situ, subsurface bioremediation efforts involving $\mathrm{Cr}^{6+}$ and other heavy metals and radionuclides.

\section{Methods}

\section{Sampling, enrichment and isolation}

A core from the saturated zone of the Ringold Formation at 25.9 meters below ground surface was obtained from a $\mathrm{Cr}^{6+}$ contaminated area on the U.S. Department of Energy's Hanford facility. The concentration of $\mathrm{Cr}^{6+}$ in the aquifer was $1.49 \mathrm{mg} / \mathrm{l}$. The core (10.2 cm diameter) was collected in a polycarbonate liner and shipped refrigerated in an argon-filled, air-tight paint can. Upon receipt, the core was refrigerated until it was aseptically pared to expose uncontaminated, internal regions that served as inocula for the experiments described below.

A 4.9 g Hanford aquifer core sample was mixed with 10 $\mathrm{ml}$ of Vogel Bonner (VB) broth [27]. Enrichments and isolations proceeded in the manner described by Fries et al. [50] using VB broth and plates. All enrichments and reductions were performed aerobically at $10^{\circ} \mathrm{C}$, with shaking (250 rpm). The isolates were labeled P2 (orange), P3 (off-white), and P4 (pale yellow), and the possible pair was labeled P1a\&b (white colonies in the beginning and pink colonies developing over time). Preliminary $\mathrm{Cr}^{6+}$ reduction observations of the three isolates in VB broth with $30 \mathrm{mg} / \mathrm{l} \mathrm{Cr}^{6+}$ revealed that only isolates $\mathrm{P} 3$ and $\mathrm{P} 4$ 
completely reduced $30 \mathrm{mg} / \mathrm{l} \mathrm{Cr}^{6+}$ in less than 60 days. Isolate $\mathrm{P} 4$ was observed to remove $\mathrm{Cr}^{6+}$ faster than $\mathrm{P} 3$ and was consequently chosen for the isolate $\mathrm{Cr}^{6+}$ reduction experiments. Isolation was confirmed via $16 \mathrm{~S}$ identification as described below.

\section{Consortium and isolate reduction experiments}

Both consortium and isolate $\mathrm{P} 4$ reduction experiments were conducted aerobically at $10^{\circ} \mathrm{C}$, with shaking $(250$ $\mathrm{rpm}$ ) and in triplicate. Consortium reductions consisted of 3 concentrations of $\mathrm{Cr}^{6+}(0,30,60 \mathrm{mg} / \mathrm{l}$ final concentration) in $4.75 \mathrm{ml}$ of $\mathrm{VB}$ broth. Final $\mathrm{Cr}^{6+}$ concentrations $(0$, $30,60 \mathrm{mg} / \mathrm{l}$ ) were achieved using a $100 \times$ stock solution of $\mathrm{Cr}^{6+}\left(3.735 \mathrm{~g} \mathrm{Cr}^{6+}\right.$ in $10 \mathrm{ml}$ distilled $\left.\mathrm{H}_{2} \mathrm{O}\right)$. The inocula consisted of $250 \mu \mathrm{l}$ of stationary phase enrichment culture $\left(10^{8} / \mathrm{ml}\right)$ bringing the total volume for each tube to $5 \mathrm{ml}$.

Isolate reductions each consisted of 3 concentrations of $\mathrm{Cr}^{6+}: 0,25,50 \mathrm{mg} / \mathrm{l}$ in $5 \mathrm{ml}$ of VB broth. Cellular biomass was first established by growing isolate $\mathrm{P} 4$ in $\mathrm{R}_{2}$ broth (Bacto Yeast Extract, $0.5 \mathrm{~g} \mathrm{~L}^{-1}$; Bacto Proteose Peptone \#3, $0.5 \mathrm{~g} \mathrm{~L}^{-1}$; Bacto Casamino Acids, $0.5 \mathrm{~g} \mathrm{~L}^{-1}$; Bacto Dextrose, $0.5 \mathrm{~g} \mathrm{~L}^{-1}$; Soluble Starch, $0.5 \mathrm{~g} \mathrm{~L}^{-1}$; Sodium Pyruvate, $0.3 \mathrm{~g}$ $\mathrm{L}^{-1}$; Dibasic Potassium Phosphate, $0.3 \mathrm{~g} \mathrm{~L}^{-1}$; Magnesium Sulfate, $\left.0.05 \mathrm{~g} \mathrm{~L}^{-1}\right)$ to stationary phase $(\mathrm{OD}=0.15$ at 600 $\mathrm{nm}$ 1:10 dilution in R2 broth). Cells were then centrifuged at 5,000 $\times \mathrm{g}$ in a Sorvall microcentrifuge (Kendro Laboratory Products, Asheville, NC) and resuspended in VB broth.

Cell-free controls and $\mathrm{Cr}^{6+}$ standards $(0,25,50,100 \mathrm{mg} /$ l) were used as the baseline for detecting $\mathrm{Cr}^{6+}$ reduction. Reduction was detected via the diphenyl carbazide assay (described below), measuring remaining $\mathrm{Cr}^{6+}$. All samples from the reduction cultures were assayed in triplicate, resulting in nine readings for each concentration. Averages and standard deviations were calculated using the spreadsheet program Excel (Microsoft) and graphed using CoPlot (CoHort Software V.6.2).

\section{Consortium $\mathrm{Cr}^{6+}$ adsorption experiments}

To confirm that observed decreases in $\mathrm{Cr}^{6+}$ concentrations were due to reduction and not biosorption, three separate adsorption studies were conducted using killed cells (autoclaved), metabolically inhibited cells, and lyophilized cells. All cells were suspended in deionized water to limit metabolic activity. Live and killed (autoclaved) cells were obtained at stationary phase, centrifuged at 5,000 $\times$ $\mathrm{g}$ for 20 minutes, washed, centrifuged (Jouan, Thermo Electron Corp.) and resuspended in an equal amount of deionized water. Lyophilized cells $(0.3 \mathrm{~g})$ were suspended in $150 \mathrm{ml}$ deionized water and allowed to rehydrate for one hour before use. Chromate concentrations were achieved using $100 \times$ stock solution of $\mathrm{Cr}^{6+}$.
Adsorption studies were conducted aerobically at 4, 10, 18 and $37^{\circ} \mathrm{C}$, with shaking (250 rpm). Concentrations of $\mathrm{Cr}^{6+}$ were analyzed by the diphenyl carbazide assay described below. Adsorption experiments were assayed in triplicate.

\section{Diphenyl carbazide assay}

A diphenyl carbazide assay for measurement of $\mathrm{Cr}^{6+}$ was developed from Standard Methods for the Examination of Water and Wastewater [51] as well as the methods listed in Turick et al. [52] with the following modifications. ChromaVer (diphenyl carbazide reagent) was obtained from Hach (Loveland, CO). Absorbance readings for reduction cultures and $\mathrm{Cr}^{6+}$ standards of $0,25,50,100$ $\mathrm{mg} / \mathrm{l}$ were recorded approximately every 48 hours for consortium cultures and every 12 hours for isolate cultures.

\section{DNA extractions}

DNA was extracted from the isolate grown in VB broth. DNA extractions were performed using the Puregene DNA Isolation Kit (Gentra systems, Minneapolis, MN). Manufacturer's instructions for Gram Positive bacteria DNA extraction were used with the following changes: cells were pelleted by centrifuging at $16,000 \times \mathrm{g}$ for 5 minutes; lysis was performed at $90^{\circ} \mathrm{C}$ for 10 minutes; lysate was treated with RNase for 60 minutes; lysate was vortexed on low speed after protein precipitation solution was added and centrifuged at $16,000 \times \mathrm{g}$ for 5 minutes; DNA was precipitated with $100 \%$ isopropanol at $-20^{\circ} \mathrm{C}$ overnight and then centrifuged at $16,000 \times \mathrm{g}$ for 5 minutes; DNA was then washed with ice cold $70 \%$ ethanol and centrifuged again at $16,000 \times \mathrm{g}$ for 5 minutes; ethanol was removed with a pipetter and the DNA was allowed to air dry at $37^{\circ} \mathrm{C}$; DNA was re-hydrated by adding $100 \mu \mathrm{l}$ molecular biology grade water and incubating overnight.

\section{PCR for I6S identification}

PCR amplification for 16S identification was performed as described by Sheridan et.al. [53]. Fragments were then sent for sequencing on an $\mathrm{ABI}$ cycle sequencer at the Molecular Research Core Facility (Idaho State University, Pocatello, ID). Fragments were sequenced in both directions.

\section{Alignment and phylogenetics}

The final contiguous sequence of 1373 base pairs was used to search both the Ribosomal Database Project http:/ /rdp.cme.msu.edu/ and Genbank http:// www.ncbi.nlm.nih.gov/ databases. Sequence fragments were aligned and analyzed as described in Sheridan et.al. [53]. The GenBank accession number for the 16S rRNA gene of isolate P4 is GenBank:DQ016989. 


\section{Authors' contributions}

WAA provided Hanford core samples and provided technical assistance. RNH performed the enrichments, isolations, reductions, adsorptions, DNA extraction, and PCR. VST lyophilized the consortium cells and provided technical assistance. RNH and PPS performed the alignment and phylogenetic analysis. RNH drafted the manuscript. All authors contributed to the experimental design and manuscript editing. All authors read and approved the final manuscript.

\section{Acknowledgements}

This work was supported in part by the Inland Northwest Research Alliance Grant \#ISU005 to PPS; and the Graduate Student Research and Scholarship Committee and the Department of Biological Sciences at Idaho State University to RNH. This work also was supported in part by the U.S. Department of Energy, Office of Science, Natural and Accelerated Bioremediation Research (NABIR) Program under DOE Idaho Operations Office Contract DE-AC07-99ID I3727, and the Environmental Management Science Program (EMSP) under contract DE-FG02-03ER63577 to WAA.

We would like to thank Erin O'Leary-Jepson and Michelle Andrews of the Idaho State University Molecular Research Core Facility for the I6S rDNA sequencing.

\section{References}

I. James BR, Bartlett R: Behavior of chromium in soils. VI. Interactions between oxidation-reduction and organic complexation. J Environ Qual 1983, 12:173-176.

2. Langard S: Biological and environmental aspects of chromium. , Elsevier Biomedical Press; 1982.

3. Panel on Micronutrients SURLNIUDRISCSEDRI: Dietary Reference Intakes for Vitamin A, Vitamin K, Arsenic, Boron, Chromium, Copper, lodine, Iron, Manganese, Molybdenum, Nickel, Silicon, Vanadium, and Zinc. Washington D.C., National Academy Press; 2002.

4. USEPA: List of Drinking Water Contaminants \& MCLs. :EPA 8I6-F-02-013 [http://www.epa.gov/ogwdw/mcl.html].

5. Committee on Ground Water Cleanup Alternatives: Alternatives for Ground Water Cleanup. Washington D.C., National Academy Press; 1994

6. Blowes D: Tracking hexavalent $\mathbf{C r}$ in groundwater. Science 2002, 295:2024-2025.

7. Allen HE, Garrison AW, Luther GW: Metals in Surface Waters. Chelsea, Michigan, Ann Arbor Press; 1998:262.

8. Langwaldt $\mathrm{JH}$, Puhakka JA: On-site biological remediation of contaminated groundwater: a review. Environmental Pollution 2000, 107:187-197.

9. Melin ES, Jarvinen KT, Puhakka JA: Effects of temperature on chlorophenol biodegradation kinetics in fluidized-bed reactors with different biomass carriers. Wat Res 1997, 32:8I-90.

10. Margesin R, Schinner F: Biodegradation and bioremediation of hydrocarbons in extreme environments. Appl Microbiol Biotechnol 200I, 56:650-653.

11. Thomassin-Lacroix EJ, Eriksson M, Reimer KJ, Mohn WW: Biostimulation and bioaugmentation for on-site treatment of weathered diesel fuel in Arctic soil. Appl Microbiol Biotechnol 2002, 59:55I-556.

12. Tseng JK, Bielefeldt AR: Low-temperature chromium(VI) biotransformation in soil with varying electron acceptors. J Environ Qual 2002, 31: 1831-I84I.

13. Francisco R, Alpoim MC, Morais PV: Diversity of chromiumresistant and -reducing bacteria in a chromium-contaminated activated sludge. J Appl Microbiol 2002, 92:837-843.

14. Srinath T, Khare S, Ramteke PW: Isolation of hexavalent chromium-reducing Cr-tolerant facultative anaerobes from tannery effluent. J Gen Appl Microbiol 200I, 47:307-3I2.

15. Gouda MK: Studies on chromate reduction by three Aspergillus species. Fresenius Envir Bull 2000, 9:799-808.
16. Wang YT, Shen H: Bacterial reduction of hexavalent chromium. J Ind Microbiol 1995, I4:159-163.

17. Viti C, Pace A, Giovannetti L: Characterization of $\mathrm{Cr}(\mathrm{VI})$-resistant bacteria isolated from chromium-contaminated soil by tannery activity. Curr Microbiol 2003, 46:I-5.

18. Fredrickson JK, Zachara JM, Kennedy DW, Duff MC, Gorby YA, Li SW, Krupka KM: Reduction of $\mathbf{U}(\mathrm{VI})$ in geothite (a-FeOOH) suspensions by a dissimilatory metal-reducing bacterium. Geochimica et Cosmochimica Acta 2000, 64:3085-3098.

19. Battaglia-Brunet F, Foucher S, Denamur A, Ignatiadis I, Michel C, Morin D: Reduction of chromate by fixed films of sulfatereducing bacteria using hydrogen as an electron source. J Ind Microbiol Biotechnol 2002, 28:154-I59.

20. Michel C, Brugna M, Aubert C, Bernadac A, Bruschi M: Enzymatic reduction of chromate: comparative studies using sulfatereducing bacteria. Key role of polyheme cytochromes $\mathrm{c}$ and hydrogenases. Appl Microbiol Biotechnol 200I, 55:95-100.

21. Rege MA, Petersen JN, Johnstone DL, Turick CE, Yonge DR, Apel WA: Bacterial reduction of hexavalent chromium by Enterobacter cloacae strain $\mathrm{HOI}$ grown on sucrose. Biotechnology Letters 1997, 19:691-694.

22. Fujii $\mathrm{E}$, Toda $\mathrm{K}$, Ohtake $\mathrm{H}$ : Bacterial reduction of toxic hexavalent chromium using a fed-batch culture of Enterobacter cloacae HOI. Journal of Fermentation and Bioengineering 1990, 69:365-367.

23. Wang PC, Mori T, Komori K, Sasatsu M, Toda K, Ohtake H: Isolation and characterization of an Enterobacter cloacae strain that reduces hexavalent chromium under anaerobic conditions. Appl Environ Microbiol 1989, 55:1665-1669.

24. Shen $\mathrm{H}$, Wang $\mathrm{Y}$ : Biological reduction of chromium by $\mathbf{E}$. coli. Journal of Environmental engineering 1994, 1 20:560-572.

25. Chirwa EMN, Wang Y: Simultaneous chromium(VI) reduction and phenol degradation $i$ an anaerobic consortium of bacteria. Wat Res 2000, 34:2376-2384.

26. Pattanapipitpaisal P, Brown NL, Macaskie LE: Chromate reduction by Microbacterium liquefaciens immobilised in polyvinyl alcohol. Biotechnology Letters 200I, 23:6I-65.

27. Bopp LH, Chakrabarty AM, Ehrlich HL: Chromate resistance plasmid in Pseudomonas fluorescens. J Bacteriol 1983, 155: I 105-1109.

28. Bopp LH, Elrich HL: Chromate resistance and reduction in Pseudomonas fluorescens strain LB300. Archives of Microbiology 1988, 150:426-431.

29. McLean J, Beveridge TJ: Chromate reduction by a pseudomonad isolated from a site contaminated with chromated copper arsenate. Appl Environ Microbiol 200I, 67:1076-1084.

30. Nepple BB, Kessi J, Bachofen R: Chromate reduction by Rhodobacter sphaeroides. Journal of Industrial Microbiology \& Biotechnology 2000, 25: 198-203.

3I. Myers CR, Carstens BP, Antholine WE, Myers JM: Chromium(VI) reductase activity is associated with the cytoplasmic membrane of anaerobically grown Shewanella putrefaciens MR-I. J Appl Microbiol 2000, 88:98-106.

32. Saxena D, Levin R, Firer MA: Removal of chromate from industrial effluent by a new isolate of Staphylococcus cohnii. Water Science and Technology 2000, 42:93-98.

33. Desjardin V, Bayard R, Huck N, Manceau A, Gourdon R: Effect of microbial activity on the mobility of chromium in soils. Waste Manag 2002, 22:195-200.

34. Kwak YH, Lee DS, Kim HB: Vibrio harveyi nitroreductase is also a chromate reductase. Appl Environ Microbiol 2003, 69:4390-4395.

35. Solisio C, Lodi A, Converti A, Del Borghi M: Cadmium, Zinc, and Chromium(III) removal from aqueous solutions by Zoogloea ramiger. Chemical and Biochemical Engineering Quarterly 1998, 12:45-49.

36. Turick CE, Apel WA: A bioprocessing strategy that allows for the selection of $\mathrm{Cr}(\mathrm{VI})$-reducing bacteria from soils. Journal of Industrial Microbiology \& Biotechnology 1997, 18:247-250.

37. Camargo FA, Bento FM, Okeke BC, Frankenberger WT: Chromate reduction by chromium-resistant bacteria isolated from soils contaminated with dichromate. J Environ Qual 2003, 32: $1228-1233$.

38. Camargo FA, Bento FM, Okeke BC, Frankenberger WT: Hexavalent chromium reduction by an actinomycete, arthrobacter crystallopoietes ES 32. Biol Trace Elem Res 2004, 97:183-194. 
39. Shen H, Wang YT: Modeling hexavalent chromium reduction in Escherichia coli 33456. Biotechnology and Bioengineering 1994, 43:293-300.

40. Shen $H$, Wang YT: Simultaneous chromium reduction and phenol degradation in a coculture of Escherichia coli ATCC 33456 and Pseudomonas putida DMP-I. Appl Environ Microbiol 1995, 6 1:2754-2758.

4I. Phillip L, Venkobachar C, lyengar L: Immobilized microbial reactor for the biotransformation of hexavalent chromium. International Journal of Environment and Pollution 1999, I I :202-210.

42. Chirwa EMN, Wang Y: Hexavalent Chromium reduction by Bacillus sp. in a packed-bed bioreactor. Environ Sci Technol I997, 3 I:|446-|45|.

43. Bader JL, Gonzalez G, Goodell PC, Ali AS, Pillai SD: Aerobic reduction of hexavalent chromim in soil by indigenous microorganisms. Bioremediation Journal 1999, 3:20I-2II.

44. Pagnanelli F, Petrangeli Papini M, Toro L, Trifoni M, Veglio F: Biosorption of metal ions on Arthrobacter sp.: Biomass characterization and biosorption modeling. Environ Sci Technol 2000, 34:2773-2778.

45. Beolchini F, Pagnanelli F, Veglio F: Modeling of copper biosorption by Arthrobacter sp. in a UF/MF membrane reactor. Environ Sci Technol 200I, 35:3048-3054.

46. Fein JB, Fowle DA, Cahill J, Kemner K, Boyanov M, Bunker B: Nonmetabolic reduction of $\mathrm{Cr}(\mathrm{VI})$ by bacterial surfaces under nutrient-absent conditions. Geomicrobiol J 2002, I9:369-382.

47. Holman HN, Perry DL, Martin MC, Lamble GM, McKinney WR, Hunter-Cevera JC: Real-time characterization of biogeochemical reduction of $\mathrm{Cr}(\mathrm{VI})$ on basalt surfaces by SR-FTIR imaging. Geomicrobiology 1999, 16:307-324.

48. Benyehuda G, Coombs J, Ward PL, Balkwill D, Barkay T: Metal resistance among aerobic chemoheterotrophic bacteria from the deep terrestrial subsurface. Can J Microbiol 2003, 49: $|5|-\mid 56$.

49. Margesin R, Schinner F: Bacterial heavy metal-toleranceextreme resistance to nickel in Arthrobacter spp. strains. J Basic Microbiol 1996, 36:269-282.

50. Fries MR, Zhou J, Chee-Sanford J, Tiedje JM: Isolation, characterization, and distribution of denitrifying toluene degraders from a variety of habitats. Appl Environ Microbiol 1994, 60:2802-2810.

51. Greenberg A, Clescerl L, Eaton A: Standard Methods for the Examination of Water and Wastewater. I8th Edition edition. Washington, D.C., American Public Health Association; 1992.

52. Turick CE, Apel WA, Carmiol NS: Isolation of hexavalent chromium-reducing anaerobes from hexavalent-chromium-contaminated and noncontaminated environments. Appl Microbiol Biotechnol 1996, 44:683-688.

53. Sheridan PP, Loveland-Curtze J, Miteva VI, Brenchley JE: Rhodoglobus vestalii gen. nov., sp. nov., a novel psychrophilic organism isolated from an Antarctic Dry Valley lake. Int J Syst Evol Microbiol 2003, 53:985-994.

\section{Publish with Biomed Central and every scientist can read your work free of charge}

"BioMed Central will be the most significant development for disseminating the results of biomedical research in our lifetime. "

Sir Paul Nurse, Cancer Research UK

Your research papers will be:

- available free of charge to the entire biomedical community

- peer reviewed and published immediately upon acceptance

- cited in PubMed and archived on PubMed Central

- yours - you keep the copyright
BioMedcentral 